\title{
Effect of a Soy Protein-Based Diet on Ribonucleic Acid Metabolism in the Small Intestinal Mucosa of Goat Kids
}

\author{
U. Schönhusen, ${ }^{\star 1}$ S. Kuhla, ${ }^{\star}$ R. Zitnan,† K. D. Wutzke,‡ K. Huber,§ S. Moors, $\|$ and J. Voigt ${ }^{\star}$ \\ "Research Unit Nutritional Physiology "Oskar Kellner," Research Institute for the Biology of Farm Animals (FBN), \\ D-181196 Dummerstorf, Germany \\ †Research Institute of Animal Production, Nitra Division Kosiče, SK-04001 Kosiče, Slovakia \\ ‡Research Laboratory, Children's Hospital, University of Rostock, D-18055 Rostock, Germany \\ §Department of Physiology, School of Veterinary Medicine Hannover, D-30173 Hannover, Germany \\ |lInstitute of Occupational Physiology at the University of Dortmund (IfADo), D-44139 Dortmund, Germany
}

\begin{abstract}
This study was designed to investigate the effect of soy protein inclusion in milk replacer diets for goat kids on protein, RNA, and DNA contents in small intestinal mucosa, on the importance of RNA biosynthesis from dietary RNA precursors for mucosal RNA synthesis, and on the activities of enzymes involved in nucleotide degradation in small intestinal mucosa. Diets were based on cow's milk. In the control group, $35 \%$ of the milk protein was replaced by casein $(\mathrm{CN})$ protein, and in the soy group (SPAA), the same amount of milk protein was replaced by soy protein supplemented with essential AA known to be at lower concentrations in soy than in CN (Thr, Val, Ile, Leu, His, Lys, Met). Diets were isonitrogenous and isoenergetic. At $47 \mathrm{~d}$ of age, goats were harvested and samples of proximal, middle, and distal jejunal mucosa were collected $5 \mathrm{~h}$ after feeding ${ }^{15} \mathrm{~N}$-labeled RNA from yeast $(13 \mathrm{mg} / \mathrm{kg}$ of body weight). Growth and feed conversion did not differ between the control and SPAA kids. Mucosal protein concentrations were lower in the SPAA than the control kids. Concentrations of RNA and DNA did not differ between feeding groups, but in all kids mucosal RNA concentrations were higher in proximal than in middle and distal jejunum. Protein:RNA ratios were higher in the control than the SPAA kids and were lowest in proximal jejunum. Activities of alkaline phosphatase in enterocytes were higher in proximal than in middle and distal jejunum. Activities of mucosal xanthine oxidase were highest in distal jejunum and were higher in the SPAA than the control kids, especially in the middle and distal sites. The ${ }^{15} \mathrm{~N}$-enrichment of mucosal RNA was higher in the control than the SPAA kids, especially in distal jejunum, and was lowest in distal
\end{abstract}

Received August 2, 2006.

Accepted January 12, 2007.

${ }^{1}$ Corresponding author: schoenhu@fbn-dummerstorf.de jejunum. In contrast, ${ }^{15} \mathrm{~N}$-enrichment of urea in plasma tended to be higher and Gly concentration in plasma was lower in the SPAA than the control kids. Data indicate that protein content and the protein:RNA ratio were lower in jejunal mucosa of goat kids fed milk replacer with partial replacement of $\mathrm{CN}$ protein by soy protein. These findings were accompanied by a lower level of reutilization of preformed dietary RNA precursors for RNA biosynthesis in jejunal mucosa and a higher activity of xanthine oxidase. Thus, feeding soy protein instead of $\mathrm{CN}$ protein reduced the incorporation of preformed dietary RNA precursors for RNA biosynthesis in the mucosa and activated key enzymes involved in nucleic acid breakdown.

Key words: soy protein, intestinal mucosa, ribonucleic acid, goat kid

\section{INTRODUCTION}

Soy protein is an economical substitute for milk protein in milk replacers for preruminants; however, animal performance is usually lower with soy protein than with milk protein diets (Lallés, 1993). Soy proteinbased diets have been demonstrated to alter intestinal structure (Silva et al., 1986; Montagne et al., 1999), with consequences for absorptive function (Seegraber and Morrill, 1986; Montagne et al., 2003) that are believed to be caused mainly by antigenic factors (e.g., immunoreactive globulins; Lallés et al., 1996), nonnutritive components (e.g., isoflavones; Chen et al., 2005), and a deficit of essential AA (e.g., Met, Lys, Ile, Thr; Kanjanapruthipong, 1998). The exposure of preruminants to soy protein milk replacer diets leads to a lower content of protein and protein:RNA ratio in small intestinal mucosa that is associated with increased cell loss and turnover (Grant et al., 1989). Dietary nucleotides can be conditionally essential nutrients with beneficial effects on intestinal growth and repair (Schlimme et al., 2000). Tissues with a rapid turnover, such as the intestinal epithelium, may use dietary nucleotides for 
incorporation in intestinal cells (Greife, 1984). There are 3 sources of nucleotides: de novo from AA (Gly, Asp, Gln), salvage of bases and ribose released by the breakdown of cellular nucleic acids (NA), and salvage of preformed nucleosides derived from the diet (Perez and Reeds, 1998; Lehninger, 2001). The relative contribution of de novo synthesis and salvage pathways seems to be affected by dietary intake (LeLeiko et al., 1983); the activities of enzymes involved in nucleotide degradation, such as alkaline phosphatase (AP; EC 3.1.3.1; Uauy et al., 1990) and xanthine oxidase (XO; EC 1.2.3.2; Furth-Walker and Amy, 1987); and the position of enterocytes within the crypt-villus axis as well as villous integrity (McCauley et al., 1998). However, in young ruminants there is no clear consensus on the relative importance of exogenous or endogenous salvage of nucleosides and de novo synthesis of nucleotides in intestinal mucosa (Boza et al., 1996). Furthermore, it is unclear whether changes in the dietary protein source that affect mucosal cell growth, as is the case for soy protein, influence nucleotide biosynthesis with respect to alterations in the use of precursors and whether changes in the dietary protein source therefore affect mucosal cell growth.

Therefore, this study was designed to examine whether feeding soy protein as a partial replacement for $\mathrm{CN}$ protein would induce differences in the extent of reutilization of exogenous nucleosides for RNA biosynthesis and whether differences in nucleotide biosynthesis would result in impaired mucosal cell growth. The soy protein diet was supplemented with essential AA, which are deficient in soy protein, to improve the protein quality of the soy diet and to avoid treatment effects caused by limitations in AA.

\section{MATERIALS AND METHODS}

\section{Animals, Diets, and Experimental Procedures}

Experimental procedures were carried out according to the animal care guidelines of the State MecklenburgVorpommern, Germany, and were approved by the relevant authorities (LVL M-V/310-4/7221.3-2.1-013/03).

Fourteen male goat kids (German White dairy goat), aged $5.5 \pm 0.5 \mathrm{~d}$, were purchased from a goat farm and transported to the Research Institute for the Biology of Farm Animals. All kids were born spontaneously and suckled colostrum and milk before removal from their dams. Kids were weighed upon receipt (mean BW of $4.5 \pm 0.2 \mathrm{~kg}$ ), and were randomly assigned by age and BW to 2 dietary treatments $(\mathrm{n}=7$ per group, respectively). Animals were housed in individual boxes at an ambient temperature of approximately $15^{\circ} \mathrm{C}$ with continuous access to fresh water. All kids were first fed progressively increasing amounts of cow's milk by bottle
Table 1. Ingredients and chemical composition of milk- or soy proteinbased diets fed to goat kids

\begin{tabular}{lcr}
\hline & \multicolumn{2}{c}{ Diet $^{1}$} \\
\cline { 2 - 3 } Item & Control & SPAA \\
\hline Ingredient, g/kg of DM feed & 752 & 727 \\
Cow milk & 100 & - \\
CN $^{2}$ & - & 160 \\
Soy protein product & \\
Lactose & 148 & 104 \\
AA mixture & - & 9 \\
Chemical & 170 & 169 \\
DM, g/kg & 41 & 49 \\
Crude ash, g/kg of DM & 307 & 307 \\
CP, g/kg of DM & 242 & 240 \\
Ether extract, g/kg of DM & 0 & 6 \\
Crude fiber, g/kg of DM & 410 & 398 \\
Nitrogen-free extracts, g/kg of DM & 404 & 351 \\
Lactose & 2.4 & 3.8 \\
RNA, g/kg of DM & 17.8 & 17.5 \\
ME, MJ/kg of DM & & \\
\hline
\end{tabular}

${ }^{1} \mathrm{Control}=$ milk diet containing $\mathrm{CN}$ protein $(35 \%$ of total $\mathrm{CP}$ in the diet); SPAA = milk diet containing soy protein supplemented with AA (35\% of total CP in the diet).

${ }^{2}$ Acid-precipitated CN (Molkereigesellschaft Lauingen mbH, Lauingen, Germany).

${ }^{3}$ Soy protein product HP 300 (Hamlet Protein A/S, Horsens, Denmark). Composition of the soy protein product (per $100 \mathrm{~g}$ of DM): 6.3 $\mathrm{g}$ of crude ash, $61.8 \mathrm{~g}$ of $\mathrm{CP}, 1.8 \mathrm{~g}$ of ether extract, $3.4 \mathrm{~g}$ of crude fiber.

${ }^{4}$ Composition of AA mixture (per $100 \mathrm{~g}$ of DM): $5 \mathrm{~g}$ of Thr, $19 \mathrm{~g}$ of Val, $7 \mathrm{~g}$ of Ile, $24 \mathrm{~g}$ of Leu, $6 \mathrm{~g}$ of His, $23 \mathrm{~g}$ of Lys, $16 \mathrm{~g}$ of Met.

feeding 3 times daily at 0700,1200 , and $1600 \mathrm{~h}$. Dietary treatments were started on d 10 of life, with a preliminary feeding period of $4 \mathrm{~d}$ during which kids were adjusted to the experimental diets, followed by a experimental feeding period of $34 \mathrm{~d}$, and ending on d 47 of life. Both experimental diets (17\% DM, $4.1 \%$ fat, $5.2 \%$ protein; Table 1) were based on cow's milk (13\% DM, $3.3 \%$ protein, $3.6 \%$ fat, $4.9 \%$ lactose). In the control group, $35 \%$ of the milk protein was replaced by $\mathrm{CN}$ protein (acid-precipitated CN, Molkereigenossenschaft $\mathrm{mbH}$, Lauingen, Germany), whereas in the soy group (SPAA) the same amount of milk protein was replaced by soy protein [soy protein product HP 300, Hamlet Protein A/S, Horsens, Denmark; $6.3 \%$ crude ash, $61.8 \%$ CP, $1.8 \%$ ether extract (EE), 3.4\% crude fiber (CF) in $\mathrm{DM}$ ] supplemented with essential AA (Thr, Val, Ile, Leu, His, Lys, Met) known to be at lower concentrations in soy protein than in CN protein (Tables 1 and 2). Diets were formulated to be isonitrogenous and isoenergetic (Table 1). Lactose was added to provide a constant proportion of protein to $\mathrm{N}$-free extracts in both diets.

Experimental diets were prepared daily by mixing the dry ingredients with fresh cow's milk and purified water. A DMI of $40 \mathrm{~g} /(\mathrm{kg} \text { of BW })^{0.75}$ per d was provided, and energy and protein were supplied at approximately 1.5 and $4.1 \times$ maintenance, respectively $[0.7 \mathrm{MJ} /(\mathrm{kg}$ of 
Table 2. Crude protein ( $\mathrm{g} / 100 \mathrm{~g}$ of $\mathrm{DM})$ and $\mathrm{AA}$ content ( $\mathrm{g} / 16 \mathrm{~g}$ of N) of milk- or soy protein-based diets fed to goat kids

\begin{tabular}{lrr}
\hline & \multicolumn{2}{c}{ Diet $^{1}$} \\
\cline { 2 - 3 } Item & Control & SPAA \\
\hline CP & 30.69 & 30.73 \\
Asp & 2 & 7.78 \\
Thr $^{2}$ & 6.84 & 3.96 \\
Ser $^{2}$ & 4.02 & 4.64 \\
Glu $^{2}$ & 5.00 & 19.03 \\
Gly $^{2}$ & 21.28 & 2.43 \\
Ala $^{2}$ & 1.78 & 3.46 \\
Val $^{2}$ & 3.06 & 6.00 \\
Ile $^{2}$ & 5.93 & 4.98 \\
Leu $^{2}$ & 5.02 & 9.06 \\
Tyr $^{2}$ & 9.03 & 3.28 \\
Phe $^{2}$ & 3.91 & 4.76 \\
His $^{2}$ & 4.78 & 2.56 \\
Lys $^{2}$ & 2.67 & 7.74 \\
Arg $^{2}$ & 7.87 & 4.10 \\
Pro $^{2}$ & 3.26 & 7.73 \\
yys $^{3}$ & 9.74 & 0.96 \\
Met $^{3}$ & 0.65 & 2.20 \\
Trp $^{4}$ & 2.30 & 1.26 \\
\hline
\end{tabular}

${ }^{1} \mathrm{Control}=$ milk diet containing $\mathrm{CN}$ protein $(35 \%$ of total $\mathrm{CP}$ in the diet); SPAA = milk diet containing a soy protein product supplemented with AA (Thr, Val, Ile, Leu, His, Lys, Met; 35\% of total CP in the diet).

${ }^{2} 6 M \mathrm{HCl}$ hydrolysis.

${ }^{3}$ Oxidation with performic acid followed by $6 \mathrm{M} \mathrm{HCl}$ hydrolysis.

${ }^{4} 4 \mathrm{M} \mathrm{NaOH}$ hydrolysis.

$\left.\mathrm{BW}^{0.75} \times \mathrm{d}\right)$ for energy and $12 \mathrm{~g} /\left(\mathrm{kg}\right.$ of $\left.\mathrm{BW}^{0.75} \times \mathrm{d}\right)$ for protein; Bezabih and Pfeffer, 2003]. Diets were warmed to $35^{\circ} \mathrm{C}$ before feeding and were fed twice daily by bottle at 0700 and $1630 \mathrm{~h}$. Kids were weighed weekly prior to the morning feeding, and DMI was adjusted for BW. Diet consumption was recorded daily, and samples of the experimental diet were collected each day and stored at $-20^{\circ} \mathrm{C}$. After the end of the experimental period, samples were thawed, pooled, and homogenized. An aliquot of $1,000 \mathrm{~g}$ was freeze-dried and used to determine ingredients. Two kids were removed from the experiment at the beginning because of clinical pneumonia so that they did not infect the others. Therefore, data are presented from 5 control and 7 SPAA kids.

To study the incorporation of ${ }^{15} \mathrm{~N}$-labeled RNA precursors derived from the diet, on experimental d 34 at the morning feeding, freeze-dried ${ }^{15} \mathrm{~N}$-labeled RNA from yeast cells $(8.6 \% \mathrm{~N}$ and $25.2 \% \mathrm{C}$ in DM, 73 atom $\%$ excess) was fed to the kids. Goat kids received 13.3 $\mathrm{mg}$ of ${ }^{5} \mathrm{~N}$-labeled RNA/kg of BW together with half the morning portion of the diet. The ${ }^{15} \mathrm{~N}$-labeled RNA used in this study was prepared from a highly enriched ${ }^{15} \mathrm{~N}$ labeled baker's yeast (Saccharomyces cerevisiae; $7.2 \%$ $\mathrm{N}$ in DM, 86 atom \% excess) as described by Crestfield et al. (1955). The baker's yeast was produced according to a method modified from the procedure described by Wutzke et al. (1984). The growth medium contained
$19 \mathrm{~g}$ of ${ }^{15} \mathrm{~N}$-ammonium chloride (95\% atom \% excess), inoculated with approximately $1 \mathrm{mg}$ of wet yeast cells. For the baseline ${ }^{15} \mathrm{~N}:{ }^{14} \mathrm{~N}$ ratio, ${ }^{15} \mathrm{~N}$-labeled RNA was replaced with the same amount of unlabeled RNA from yeast (14.3\% N, 31.9\% C in DM, Serva, Heidelberg, Germany) and given to 1 kid of the SPAA group and 1 kid of the control group. Because 2 kids in the control group had to be removed from the experiment, unlabeled baseline data for the control group were taken from 1 animal that had received unlabeled RNA in a preliminary study.

Five hours after feeding, the kids were killed by stunning using a captive bolt pistol and were exsanguinated by jugular puncture. Blood samples were taken in tubes containing dipotassium EDTA (1.6 mg/mL of blood) and held on crushed ice. Plasma was aliquoted after centrifugation $\left(1,500 \times \mathrm{g}, 15 \mathrm{~min}\right.$ at $\left.4^{\circ} \mathrm{C}\right)$ and stored at $-20^{\circ} \mathrm{C}$ for later analysis. The abdominal cavity was immediately opened and the jejunum was totally removed and divided into 3 equal segments (proximal, middle, distal). These segments were rinsed free of digesta with ice-cold saline $(0.9 \% \mathrm{NaCl}$, wt/vol). Total tissue sections of $1 \mathrm{~g}$ from jejunal segments were cut for preparation of epithelial cells, frozen in liquid $\mathrm{N}$, and stored at $-80^{\circ} \mathrm{C}$. Mucosal tissue from each segment was harvested by scraping with a glass slide. Mucosa was portioned, frozen in liquid $\mathrm{N}$, and stored at $-80^{\circ} \mathrm{C}$. Approximately 3 $\mathrm{g}$ of frozen tissue was freeze-dried, air-equilibrated, and ground with a ball mill (particle size $1 \mu \mathrm{m}$; MM2, Retsch, Haan, Germany).

\section{Analytical Procedures}

Feed. Dry matter, crude ash, EE, and CF of the dried dietary components and experimental diets were determined following the Weende standard procedure (Naumann and Bassler, 1993). Total $\mathrm{N}$ was determined by a combustion analyzer (CNS-2000, Leco, St. Joseph, MI). Crude protein was calculated by $\mathrm{N} \times 6.25$. Lactose concentration was measured by the $\beta$-galactosidase method using a commercial kit (No. 10176303 035, RBiopharm AG, Darmstadt, Germany). Dietary AA concentrations were measured by liquid ion-exchange chromatography (Biochrom 20, Pharmacia LKB Biochrom Ltd., Cambridge, UK) following $6 M \mathrm{HCl}$ hydrolysis (22 $\mathrm{h}$ at $110^{\circ} \mathrm{C}$ ) except for Trp, for which a $4 \mathrm{M} \mathrm{NaOH}$ hydrolysis was used $\left(26 \mathrm{~h}\right.$ at $\left.110^{\circ} \mathrm{C}\right)$. Cysteine and Met were determined as cysteic acid and methionine sulfone after oxidation with performic acid $\left(16 \mathrm{~h}\right.$ at $\left.0^{\circ} \mathrm{C}\right)$, followed by $6 \mathrm{M} \mathrm{HCl} \mathrm{hydrolysis}\left(22 \mathrm{~h}\right.$ at $\left.110^{\circ} \mathrm{C}\right)$. No corrections were made for losses of AA during hydrolysis. Ribonucleic acid in the diets was determined in a 500mg sample (particle size of $1 \mu \mathrm{m}$ ) after salt extraction by an orcinol-HCl procedure (Schönhusen et al., 1988), 
with RNA (low molecular weight from yeast, $14.5 \% \mathrm{~N}$, Serva, Heidelberg, Germany) as the standard (125 $\mu \mathrm{g} /$ $\mathrm{mL}$ ). The total $\mathrm{N}$ content in prepared ${ }^{15} \mathrm{~N}$-labeled baker's yeast and in ${ }^{15} \mathrm{~N}$-labeled RNA from yeast cells was analyzed by the Dumas combustion method (CNS2000, Leco).

Mucosal Protein, RNA, and DNA. Concentrations of protein in mucosal tissue homogenates $(200 \mathrm{mg}$ of wet sample homogenized in $1 \mathrm{~mL}$ of saline, $1 \mathrm{~min}$ ) were determined by the method of Lowry et al. (1951) with BSA (Fraction V, Sigma-Aldrich Co., St. Louis, MO) as the standard. Ribonucleic acid was determined after extraction from a $100-\mathrm{mg}$ sample of freeze-dried mucosal tissue according to the method described by Schönhusen and Voigt (2004). The guanidine-isothiocyanatephenol procedure (Chomczynski and Sacchi, 1987) was used to analyze DNA concentrations in epithelial tissue. A 10-mg sample of freeze-dried mucosal tissue was homogenized in $1 \mathrm{~mL}$ of peqGOLDTriFast (peqLab Biotechnologie $\mathrm{GmbH}$, Erlangen, Germany) for $1 \mathrm{~min}$ at 13,500 U/min (UltraTurrax T 25, IKA-Werke GmbH, Staufen, Germany), and centrifuged $(12,000 \times g, 10 \mathrm{~min}$ at $4^{\circ} \mathrm{C}$ ). After lysis, DNA was isolated from the interphase and phenol phase, separated with chloroform by successive precipitations with ethanol, and dissolved in $8 \mathrm{mM} \mathrm{NaOH}\left(5 \mathrm{~d}\right.$ at $\left.4^{\circ} \mathrm{C}\right)$. Absorption was measured at $260 \mathrm{~nm}$ (Ultrospec 2100 pro, Amersham Pharmacia Biotech, Cambridge, UK). Concentrations of DNA in the mucosa were used as an index of tissue hyperplasia (increase in cell number), and RNA:DNA and protein:DNA ratios were used as indexes of tissue hypertrophy (increase in cell size; Burrin et al., 1992).

Mucosal and Plasma ${ }^{15} \mathrm{~N}$-Enrichments. The ${ }^{15} \mathrm{~N}:{ }^{14} \mathrm{~N}$ ratios of RNA in mucosa and urea in plasma were measured by means of an isotope ratio mass spectrometer (Delta S, Finnigan MAT, Bremen, Germany) after combustion of the samples by an elemental analyzer (Carlo Erba, Milan, Italy). The ${ }^{15} \mathrm{~N}$ enrichments (expressed in atom \% excess) were calculated from the $\delta$ values (Wolfe and Chinkes, 2005). The standard gas was calibrated against atmospheric air N. Sample sizes of 20 to $50 \mu \mathrm{g}$ of $\mathrm{N}$ (RNA) and $100 \mu \mathrm{g}$ of N (urea) were used for combustion. Corrections regarding atom \% excess were obtained by subtraction of the basal abundance measured in samples from unlabeled goat kids. For analysis of the ${ }^{15} \mathrm{~N}:{ }^{14} \mathrm{~N}$ ratio in mucosal RNA, the RNA was isolated from a 100-mg sample of freeze-dried mucosal tissue (Schönhusen and Voigt, 2004). The RNA pellet separated from DNA and protein contamination was brought up to a final volume of $100 \mathrm{~mL}$ with distilled water. Five milliliters was used to estimate the RNA content by the modified orcinol test (Markham, 1955). The calibration was done with RNA from yeast $(125 \mu \mathrm{g} / \mathrm{mL}, 14.5 \% \mathrm{~N}$, Serva). In the remaining $95 \mathrm{~mL}$,
RNA was destroyed with $10 \mathrm{~mL}$ of $97 \% \mathrm{H}_{2} \mathrm{SO}_{4}$ (wt/vol, containing $5 \mathrm{~g}$ of Se/L $+5 \mathrm{~mL}$ of $\mathrm{H}_{2} \mathrm{O}_{2} / \mathrm{L}$ ) according to the Kjeldahl procedure. The distillate was taken up in $9 \mathrm{~mL}$ of $0.02 \mathrm{M} \mathrm{HCl}$ and evaporated to dryness at $60^{\circ} \mathrm{C}$ in a forced-air oven (UT 6060, Heraeus, Osterode, Germany). The residue was dissolved in $100 \mu \mathrm{L}$ of doubledistilled water. A $35-\mu \mathrm{L}$ volume of diluted residue was transferred into a combustion capsule (Fisons, Code 2406400 , Ipswich, UK), dried at $60^{\circ} \mathrm{C}$, and used for measurement of the ${ }^{15} \mathrm{~N}:{ }^{14} \mathrm{~N}$ ratio as described above. For analysis of the ${ }^{15} \mathrm{~N}:{ }^{14} \mathrm{~N}$ ratio in plasma urea, 500 $\mu \mathrm{L}$ of plasma was incubated with $1 \mathrm{~mL}$ of a urease containing $\mathrm{KH}_{2}$-phosphate: $\mathrm{Na}_{2} \mathrm{H}$-phosphate buffer $(66.7 \mathrm{mM})$ at $\mathrm{pH} 7.0$ for $3 \mathrm{~h}$ at $40^{\circ} \mathrm{C}$. The resultant $\mathrm{NH}_{3}$ was separated by microdiffusion (Voigt and Steger, 1967), taken up in $5 \mathrm{~mL}$ of $0.01 \mathrm{M} \mathrm{HCl}$, and prepared for measurement of the ${ }^{15} \mathrm{~N}:{ }^{14} \mathrm{~N}$ ratio as described above.

By means of the ${ }^{15} \mathrm{~N}:{ }^{14} \mathrm{~N}$ ratio analyses, the incorporation of preformed ${ }^{15} \mathrm{~N}$-labeled RNA precursors derived from the diet into a newly synthesized mucosa RNA can be traced and the relative proportion of pathways for RNA biosynthesis can therefore be presented. The ${ }^{15} \mathrm{~N}$-enrichment in plasma urea can provide information on the degradation of nucleosides and purine bases of dietary origin. To exclude an isotopic dilution effect in SPAA tissue, enrichments were corrected. The ${ }^{15} \mathrm{~N}$ enrichment (atom \% excess) in mucosal RNA and plasma urea of SPAA kids was multiplied by a factor of 1.3 to adjust the ${ }^{15} \mathrm{~N}:{ }^{14} \mathrm{~N}$ ratio. This allowed a comparison of ${ }^{15} \mathrm{~N}:{ }^{14} \mathrm{~N}$ on an equivalent basis relative to intake.

Plasma Glycine. The concentration of free Gly in blood plasma was measured after deproteinization with sulfosalicylic acid (35\%, wt/vol) by ion-exchange chromatography using a lithium buffer $(0.3 M)$ and a physiological AA standard solution (no. A9906, Sigma-Aldrich Co.) with an AA analyzer (Biochrom 20, Pharmacia LKB, Cambridge, UK).

Mucosal Enzyme Activities. The AP activity in enterocytes was calculated from photometric measurements as the rate of hydrolysis of $p$-nitrophenyl phosphate according to an assay kit (No. 816388, Roche Diagnostics, Mannheim, Germany). Results were expressed as micromoles of $p$-nitrophenyl phosphate converted per minute per milligram of protein in the cell suspension. Protein was determined by the method of Bradford (1976) with a Bioquant-Protein reagent solution (Merck, Darmstadt, Germany) using BSA as the standard. For measurement of XO activity in mucosal tissue of the jejunum, $500 \mathrm{mg}$ of wet mucosal tissue was homogenized for $45 \mathrm{~s}$ in $3 \mathrm{~mL}$ of $0.05 M$ HEPES buffer ( $\mathrm{pH}$ 7.5) containing $0.25 \mathrm{mM}$ EDTA and $0.25 M$ phenylmethylsulfonyl fluoride using a Potter-Elvehjem tissue grinder with a Teflon pestle and then centrifuged $\left(30,000 \times g, 20 \mathrm{~min}\right.$ at $\left.4^{\circ} \mathrm{C}\right)$. The supernatant fraction 
was dialyzed against the same buffer $\left(24 \mathrm{~h}, 4^{\circ} \mathrm{C}\right)$ and centrifuged $\left(26,000 \times g, 30 \mathrm{~min}\right.$ at $\left.4^{\circ} \mathrm{C}\right)$. Sample preparation was adapted from Furth-Walker and Amy (1987). Activity of XO was measured as the rate of uric acid production when a xanthine substrate was incubated with mucosal extracts. The rate of uric acid production was defined as $1 \mathrm{U}$ of XO activity producing $1 \mu \mathrm{mol}$ of uric acid $/ \mathrm{min}$ at $37^{\circ} \mathrm{C}$. The results were expressed as micromoles of uric acid generated per minute and milligram of protein in the mucosal homogenates. Protein was determined by the method of Lowry et al. (1951).

\section{Calculations and Statistical Procedures}

The ME content of feed was calculated using the digestible $(d)$ nutrients as follows (GfE, 2001):

$$
\begin{gathered}
\mathrm{ME}(\mathrm{MJ})=0.0312 \times d \mathrm{EE}(\mathrm{g})+0.0136 \times d \mathrm{CF}(\mathrm{g})+0.0147 \\
\times(d \mathrm{OM}-d \mathrm{EE}-d \mathrm{CF})(\mathrm{g})+0.00234 \times \mathrm{CP}(\mathrm{g}) .
\end{gathered}
$$

Digestible nutrients were calculated from the measured nutrient contents multiplied by the digestibility of nutrients using feedstuff tables (Jentsch et al., 2003). The ${ }^{15} \mathrm{~N}$-enrichments of mucosal RNA and of urea in plasma, expressed in atom \% excess, were calculated from the $\delta$ values according to the equations reported by Wolfe and Chinkes (2005).

Data were expressed as means \pm standard errors of the means. Data on growth (based on BW at the beginning and end of the experiment), and plasma concentrations of ${ }^{15} \mathrm{~N}$-urea and Gly were evaluated using the $t$-test procedure of SAS (v. 9.1; SAS Institute, 2004). Differences between feeding groups were defined, with $P<0.1$ for a trend and $P<0.05$ for a significant difference. Data for mucosal RNA metabolism and enzyme activities were analyzed by the Mixed procedure of SAS using feeding and intestinal segment as fixed effects and individual goats as random effects. For the evaluation of differences in intestinal segments within feeding groups, the feeding $\times$ intestinal segment interactions were included in the model. Differences were localized by Tukey's $t$-test, with $P<0.1$ for a trend and $P<0.05$ for a significant difference.

\section{RESULTS}

\section{Feed Intake, BW, and Health Status}

Daily intakes of DM, CP, and ME per animal were not different between the control and SPAA group, respectively (Table 3). The intake of RNA and Gly was higher in the SPAA group than in the control group because of the soy protein component. No differences in the initial and final mean BW existed between groups.
Table 3. Intake, BW, and feed efficiency of goat kids fed milk- or soy

\begin{tabular}{|c|c|c|}
\hline \multirow[b]{2}{*}{ Item } & \multicolumn{2}{|c|}{ Diet $^{1}$} \\
\hline & Control & SPAA \\
\hline \multicolumn{3}{|l|}{ Intake } \\
\hline $\mathrm{DM}, \mathrm{g} /($ animal $\times \mathrm{d})$ & $151 \pm 10$ & $166 \pm 5$ \\
\hline $\mathrm{CP}, \mathrm{g} /($ animal $\times \mathrm{d})$ & $46 \pm 3$ & $51 \pm 1$ \\
\hline $\mathrm{RNA}, \mathrm{mg} /($ animal $\times \mathrm{d})$ & $363 \pm 25$ & $628 \pm 18^{* * *}$ \\
\hline Gly, $\mathrm{g} /($ animal $\times \mathrm{d})$ & $0.82 \pm 0.07$ & $1.24 \pm 0.04 * * *$ \\
\hline $\mathrm{ME}, \mathrm{MJ} /($ animal × d) & $2.7 \pm 0.2$ & $2.9 \pm 0.1$ \\
\hline \multicolumn{3}{|l|}{ BW } \\
\hline At start (14 d of age), $\mathrm{kg}$ & $4.7 \pm 0.3$ & $4.8 \pm 0.2$ \\
\hline At end ( $47 \mathrm{~d}$ of age), $\mathrm{kg}$ & $9.1 \pm 0.6$ & $9.3 \pm 0.2$ \\
\hline BW gain, g/d & $133 \pm 8$ & $138 \pm 4$ \\
\hline Feed efficiency, g of DMI/g of BW gain & $1.13 \pm 0.02$ & $1.21 \pm 0.03$ \\
\hline
\end{tabular}
protein-based diets

${ }^{1}$ Values are means \pm SEM (control, $\mathrm{n}=5$; SPAA, $\mathrm{n}=7$ ). Control = milk diet containing $\mathrm{CN}$ protein (35\% of total $\mathrm{CP}$ in the diet); SPAA = milk diet containing soy protein supplemented with AA (Thr, Val, Ile, Leu, His, Lys, Met; 35\% of total CP in the diet).

*** $P<0.001$ between diets.

Average daily gain and feed conversion also did not differ between groups (Table 3). Because there were no differences in feed intake and growth during the experimental period (for each week), data are not presented herein. Fecal consistency was pasty, lasting for 1 and $3 \mathrm{~d}$, in 2 control and 4 SPAA kids in the middle of the experimental period. The remaining goat kids were healthy and showed no differences in their behavior.

\section{Mucosal Metabolites and Enzymes}

Mucosal protein concentrations were lower $(P<0.01)$ in the SPAA than in the control group (Table 4). Concentrations of RNA and DNA in jejunal mucosa did not differ between feeding groups, but mucosal RNA concentrations were higher $(P<0.01)$ in proximal than in middle and distal jejunum (Table 4). The protein:RNA ratios were higher $(P<0.05)$ in the control than in the SPAA group and were lowest $(P<0.05)$ in proximal jejunum (Table 4).

Activities of AP in enterocytes were higher $(P<0.05)$ in proximal than in middle and distal jejunum (Figure 1A). Activities of mucosal XO were highest in distal jejunum and were higher $(P<0.01)$ in the SPAA than in the control group, especially in middle and distal jejunum (Figure 1B).

\section{${ }^{15} \mathrm{~N}$-Enrichment in Mucosal RNA and Blood Plasma Urea}

Isotopic RNA enrichment differed $(P<0.05)$ between the control and SPAA groups, especially overall in distal jejunum, and were lowest $(P<0.01)$ in distal jejunum. The isotopic enrichment in plasma urea tended to be 
Table 4. Concentrations of protein, RNA, DNA, and RNA:DNA, protein:DNA, and protein:RNA ratios in the jejunal mucosa of goat kids fed milk- or soy protein-based diets

\begin{tabular}{|c|c|c|c|c|c|c|}
\hline \multirow[b]{2}{*}{ Item } & \multirow[b]{2}{*}{ Site $^{1}$} & \multicolumn{2}{|c|}{$\operatorname{Diet}^{2}$} & \multicolumn{3}{|c|}{ ANOVA, $P$-value } \\
\hline & & Control & SPAA & Diet & Site & Diet $\times$ site \\
\hline \multirow[t]{3}{*}{ Protein, mg/g of mucosa $a^{3}$} & $\mathrm{P}$ & $851 \pm 50$ & $735 \pm 16$ & & & \\
\hline & M & $823 \pm 40$ & $692 \pm 47$ & 0.01 & NS & NS \\
\hline & $\mathrm{D}$ & $798 \pm 52$ & $694 \pm 36$ & & & \\
\hline \multirow[t]{3}{*}{ RNA, mg/g of mucosa ${ }^{3}$} & $\mathrm{P}$ & $33.4 \pm 1.7$ & $34.3 \pm 1.3$ & & & \\
\hline & M & $26.3 \pm 0.7$ & $26.0 \pm 0.6$ & NS & 0.001 & NS \\
\hline & $\mathrm{D}$ & $25.9 \pm 0.7$ & $25.3 \pm 0.9$ & & & \\
\hline \multirow[t]{3}{*}{ DNA, mg/g mucosa ${ }^{3}$} & $\mathrm{P}$ & $16.5 \pm 0.5$ & $17.2 \pm 1.3$ & & & \\
\hline & $\mathrm{M}$ & $16.0 \pm 1.6$ & $15.7 \pm 1.8$ & NS & NS & NS \\
\hline & D & $17.5 \pm 3.2$ & $17.4 \pm 1.3$ & & & \\
\hline \multirow[t]{3}{*}{ RNA:DNA } & $\mathrm{P}$ & $2.02 \pm 0.10$ & $2.05 \pm 0.13$ & & & \\
\hline & M & $1.71 \pm 0.18$ & $1.88 \pm 0.30$ & NS & NS & NS \\
\hline & D & $1.63 \pm 0.22$ & $1.50 \pm 0.13$ & & & \\
\hline \multirow[t]{3}{*}{ Protein:DNA } & $\mathrm{P}$ & $51.5 \pm 2.8$ & $44.1 \pm 3.0$ & & & \\
\hline & M & $53.6 \pm 6.5$ & $49.8 \pm 8.5$ & NS & NS & NS \\
\hline & $\mathrm{D}$ & $49.0 \pm 5.3$ & $41.6 \pm 4.4$ & & & \\
\hline \multirow[t]{3}{*}{ Protein:RNA } & $\mathrm{P}$ & $25.8 \pm 1.9$ & $21.7 \pm 1.0$ & & & \\
\hline & $\mathrm{M}$ & $31.4 \pm 1.7$ & $26.9 \pm 2.4$ & 0.05 & 0.01 & NS \\
\hline & $\mathrm{D}$ & $31.0 \pm 2.5$ & $27.7 \pm 1.7$ & & & \\
\hline
\end{tabular}

\footnotetext{
${ }^{1}$ Jejunal site: $\mathrm{P}=$ proximal; $\mathrm{M}=$ medial; $\mathrm{D}=$ distal.

${ }^{2}$ Values are means \pm SEM (control, $\mathrm{n}=5$; SPAA $\mathrm{n}=7$ ). Control $=$ milk diet containing $\mathrm{CN}$ protein $(35 \%$ of total CP in the diet); SPAA = milk diet containing soy protein supplemented with AA (Thr, Val, Ile, Leu, His, Lys, Met; $35 \%$ of total CP in the diet).

${ }^{3}$ Freeze-dried tissue.
}

higher $(P<0.1)$ in the SPAA than in the control group (Table 5).

\section{Blood Plasma Concentrations of Gly}

Plasma Gly concentrations were higher $(P<0.05)$ in control than in SPAA ( $683 \pm 31$ vs. $538 \pm 36 \mathrm{nmol} / \mathrm{mL})$.

\section{DISCUSSION}

Partial replacement of $\mathrm{CN}$ protein in milk diets for goat kids by soy protein supplemented with AA did not affect body growth. This was expected because the concentrations of 7 essential AA (Thr, Val, Ile Leu, His, Lys, and Met) added to SPAA were equivalent to that in the control diet. This is in contrast to the reduced growth and inefficient AA utilization for body protein synthesis reported in several studies with young preruminant animals fed milk replacers containing soy protein without AA supplementation (Kanjanapruthipong, 1998).

Feeding the SPAA diet caused a reduced mucosal protein concentration and a reduced protein:RNA ratio in jejunum compared with the control diet. In agreement with this result, others have shown an association between reduced protein synthesis and a decreased protein:RNA ratio in the proximal small intestinal mucosa (Núnez et al., 1996). Among intestinal segments, we found no differences in protein concentra- tions, but RNA content was greatest and the protein:RNA ratio was lowest in proximal jejunum. In calves fed a milk replacer with $20 \%$ of total protein from soy protein and supplemented with dietary amines, Grant et al. (1989) also reported a reduced mucosal protein concentration, reduced epithelial cell proliferation, and diminished efficiency of epithelial protein synthesis in the small intestinal mucosa.

Razzaque et al. (1981) showed that the breakdown products of dietary NA are salvaged and feed into a synthetic pathway in preruminant lambs, and that purine bases may be more important than nucleosides as NA precursors. In the study by Razzaque (1981), incorporation of radioactivity from ${ }^{14} \mathrm{C}$-labeled bacterial NA into body tissues was found after $24 \mathrm{~h}$, and much of this activity was located in the small intestine. In SPAA kids, ${ }^{15} \mathrm{~N}$-RNA enrichment in the mucosa, particularly of the distal jejunum, was lower than that in control kids, indicating that soy protein reduced the ability to reutilize preformed RNA precursors of dietary origin into newly synthesized mucosa RNA. Instead, the excess nucleosides and N-bases were probably degraded. In line with this, the tendency for higher ${ }^{15} \mathrm{~N}$ enrichment in plasma urea in SPAA kids suggests a higher degradation of dietary nucleotides and nucleosides. In rat small intestine, the activity of enzymes involved in NA breakdown changed in response to the diet, especially to dietary protein (Furth-Walker and Amy, 1987). The catabolism of purines was regulated 


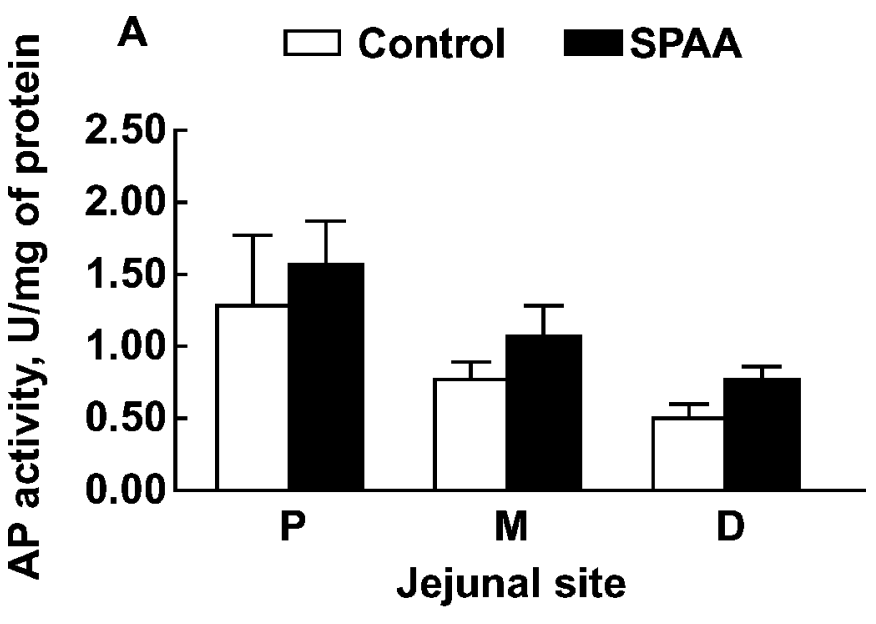

B

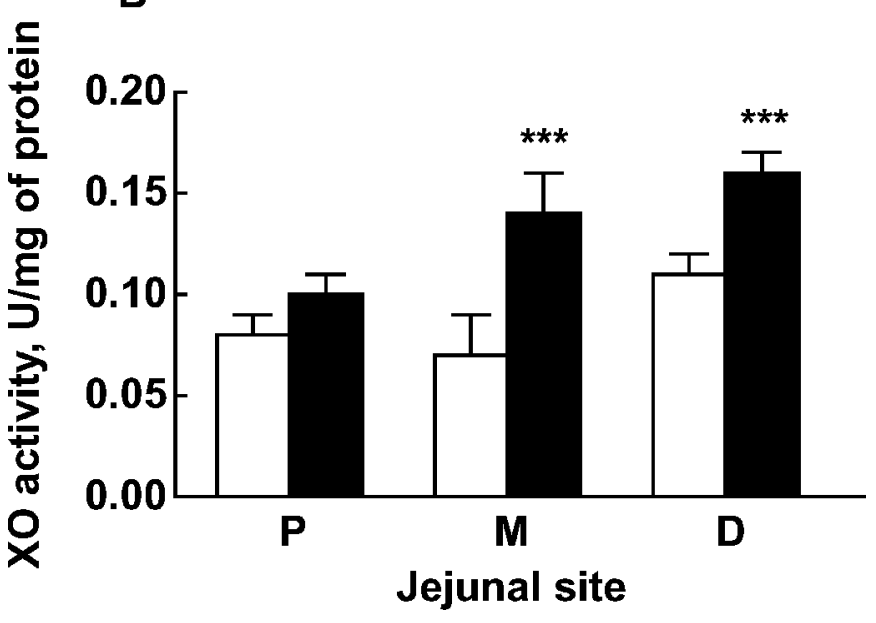

Figure 1. Enzyme activities of alkaline phosphatase (AP) in enterocytes and xanthine oxidase (XO) in mucosal homogenates in the jejunum of goat kids fed milk- or soy protein-based diets. Values are means \pm SEM (control, $\mathrm{n}=5$; SPAA, $\mathrm{n}=7$ ). Control $=$ milk diet containing $\mathrm{CN}$ protein (35\% of total $\mathrm{CP}$ in the diet); SPAA = milk diet containing soy protein supplemented with AA (Thr, Val, Ile, Leu, His, Lys, Met; $35 \%$ of total CP in the diet). Jejunal site: $\mathrm{P}=$ proximal; $\mathrm{M}=$ medial; $\mathrm{D}=$ distal. For AP activity, $1 \mathrm{U}$ catalyzes the hydrolysis of $1 \mu \mathrm{mol}$ of $p$-nitrophenyl phosphate/min at $37^{\circ} \mathrm{C}$; for $\mathrm{XO}$ activity, $1 \mathrm{U}$ produces $1 \mu \mathrm{mol}$ of uric acid $/ \mathrm{min}$ at $37^{\circ} \mathrm{C}$. ANOVA ( $P$-value) for AP: diet $=$ NS, site $=0.05$, diet $\times$ site $=$ NS; ANOVA $(P$-value $)$ for XO: diet $=0.001$, site $=\mathrm{NS}$, diet $\times$ site $=0.001$. Between diets: $\dagger P<$ $0.1, * P<0.05, * * * P<0.001$.

in the intestinal tract by enzyme activities such as AP and $\mathrm{XO}$ in the mouse proximal gastrointestinal tract (Witte et al., 1991). We found a higher XO activity in the jejunal mucosa of SPAA kids when compared with control kids. However, AP activity in the intestinal mucosa was much less responsive to the protein source in the diet than was XO. Various investigators have postulated that $\mathrm{XO}$ is a rate-limiting enzyme in NA breakdown (Parks and Granger, 1986), and its increase in activity may cause a lack of nucleosides for incorporation into mucosal RNA. The increased XO activities in SPAA are in agreement with the lower ${ }^{15} \mathrm{~N}$-enrichment in mucosal RNA in the jejunum as well as with the higher plasma urea ${ }^{15} \mathrm{~N}$-enrichment, indicating a higher degradation of nucleosides and purine bases.

Furthermore, the dietary supply of nucleosides or purines and AA may affect the balance between salvage and de novo synthesis in the small intestinal mucosa (Schlimme et al., 2000). As shown in rats fed diets deficient in purines, increased incorporation of Gly into mucosa purine nucleotides via de novo pathway could be demonstrated when the diet contained protein (LeLeiko et al., 1983). Lower plasma concentrations, but a greater intake of Gly, in SPAA kids may suggest that Gly was used for de novo purine nucleotide biosynthesis in mucosa. However, we did not measure de novo RNA synthesis in our study. In addition, changes in endogenous salvage of cellular nucleotide breakdown attributable to soy feeding cannot be excluded, but were not measured. Our data indicate no differences in mucosal RNA concentration between SPAA and control kids. Overall, the lower incorporation of preformed RNA fits with the current hypotheses of an altered salvage of dietary nucleosides for NA synthesis after soy feeding. Therefore, an increase in de novo purine nucleotide synthesis, an elevated use of the endogenous salvage pathway for RNA synthesis, or both could be presumed in soy-fed goat kids.

In summary, a lower protein content and a lower protein:RNA ratio in the small intestinal mucosa of goat kids induced by partial replacement of $\mathrm{CN}$ protein by soy protein supplemented with AA was accompanied by a lower isotopic enrichment in mucosal RNA especially in the distal small intestine. This indicates a reduced reutilization of RNA precursors of dietary origin to provide nucleotides for mucosal RNA biosynthesis via the salvage pathway in soy-fed kids. Soy protein stimulates the activity of mucosal XO involved in NA breakdown, which could partly explain lower salvaging of breakdown products of dietary RNA precursors for mucosal RNA biosynthesis. Our findings support an altered RNA metabolism in the small intestinal mucosa when soy protein is fed instead of $\mathrm{CN}$. The impact of these changes on mucosal cell growth requires further investigation to clarify whether intestinal function is affected by the changes in intestinal RNA metabolism.

\section{ACKNOWLEDGMENTS}

The authors wish to express their gratitude to C. C. Metges and H. M. Hammon for assistance in manuscript preparation and B. Waischnow and M. Althaus for excellent technical assistance. 
Table 5. ${ }^{15} \mathrm{~N}$-enrichment (atom \% excess) in RNA isolated from jejunal mucosa and in plasma urea of goat kids $5 \mathrm{~h}$ after administration of ${ }^{15} \mathrm{~N}$-labeled RNA with a milk- or soy protein-based diet

\begin{tabular}{|c|c|c|c|c|c|}
\hline \multirow[b]{2}{*}{ Item } & \multicolumn{2}{|c|}{$\operatorname{Diet}^{1}$} & \multicolumn{3}{|c|}{ ANOVA, $P$-value } \\
\hline & Control & SPAA & Diet & Site & Diet $\times$ site \\
\hline \multicolumn{6}{|l|}{$\begin{array}{l}{ }^{15} \mathrm{~N}-\text { enrichment in mucosal } \\
\text { RNA in jejunum }{ }^{2}\end{array}$} \\
\hline $\mathrm{P}$ & $0.110 \pm 0.003$ & $0.114 \pm 0.005$ & & & \\
\hline $\mathrm{M}$ & $0.109 \pm 0.008$ & $0.106 \pm 0.010$ & 0.05 & 0.01 & 0.05 \\
\hline $\mathrm{D}$ & $0.098 \pm 0.028$ & $0.031 \pm 0.003^{*}$ & & & \\
\hline${ }^{15} \mathrm{~N}$-enrichment in plasma urea & $0.065 \pm 0.002$ & $0.075 \pm 0.004 \dagger$ & 0.08 & - & - \\
\hline
\end{tabular}

${ }^{1}$ Values are means \pm SEM (control, $\mathrm{n}=5$; SPAA, $\mathrm{n}=6$ ). Control $=$ milk diet containing $\mathrm{CN}$ protein $(35 \%$ of total CP in the diet); SPAA = milk diet containing soy protein supplemented with AA (Thr, Val, Ile, Leu, His, Lys, Met; $35 \%$ of total CP in the diet).

${ }^{2}$ Freeze-dried tissue. Jejunal site: $\mathrm{P}=$ proximal; $\mathrm{M}=$ medial; $\mathrm{D}=$ distal.

$\dagger P<0.1, * P<0.05$ between diets.

\section{REFERENCES}

Bezabih, M., and E. Pfeffer. 2003. Body chemical composition and efficiency of energy and nutrient utilization by growing pre-ruminant Saanen goat kids. J. Anim. Sci. 77:155-163.

Boza, J. J., F. Jahoor, and P. J. Reeds. 1996. Ribonucleic acid nucleotides in maternal and fetal tissues derive almost exclusively from synthesis de novo in pregnant mice. J. Nutr. 126:1749-1758.

Bradford, M. M. 1976. A rapid and sensitive method for the quantification of microgram quantities of protein utilizing the principle of protein-dye binding. Anal. Biochem. 72:248-254.

Burrin, D. G., R. A. Britten, C. L. Farell, and M. L. Bauer. 1992. Level of nutrition and visceral organ protein synthetic capacity and nucleic acid content in sheep. J. Anim. Sci. 70:1137-1145.

Chen, A. C., M. A. Berhow, K. A. Tappenden, and S. M. Donovan. 2005. Genistein inhibits intestinal cell proliferation in piglets. Pediatr. Res. 57:192-200.

Chomczynski, P., and N. Sacchi. 1987. Single step method of RNA isolation, by guanidinium thiocyanate-phenol-chloroform extraction. Anal. Biochem. 162:156-159.

Crestfield, A. M., K. C. Smith, and F. W. Allen. 1955. The preparation and characterization of ribonucleic acids from yeasts. J. Biol. Chem. 216:185-193.

Furth-Walker, D., and N. K. Amy. 1987. Regulation of xanthine oxidase activity and immunological detectable protein in rats in response to dietary protein and iron. J. Nutr. 117:1697-1703.

GfE (Gesellschaft für Ernährungsphysiologie). 2001. Ausschuss für Bedarfsnormen der Gesellschaft für Ernährungsphysiologie. No. 8 Empfehlungen zur Energie- und Nährstoffversorgung der Milchkühe und Aufzuchtrinder. DLG-Verlag, Frankfurt am Main, Germany.

Grant, A. E., R. E. Holland, J. W. Thomas, K. J. King, and J. S. Liesman. 1989. Effects of dietary amines on the small intestine in calves fed soybean protein. J. Nutr. 119:1034-1041.

Greife, H. A. 1984. Enteraler und intermediärer Nukleinsäurestoffwechsel. Übers. Tierernähr. 12:1-44.

Jentsch, W., A. Chudy, and M. Beyer. 2003. Reference numbers of feed value and requirement on the base of net energy. Rostock Feed Evaluation System. Plexus Verlag, Miltenberg-Frankfurt, Germany.

Kanjanapruthipong, J. 1998. Supplementation of milk replacers containing soy protein with threonine, methionine, and lysine in the diets of calves. J. Dairy Sci. 81:2912-2915.

Lallés, J. P. 1993. Nutritional and anti-nutritional aspects of soybean and field pea proteins used in veal calf production: A review. Livest. Prod. Sci. 34:181-202.

Lallés, J. P., D. Dreau, H. Salmon, and R. Toullec. 1996. Identification of soybean allergens and immune mechanisms of dietary sensitivities in pre-ruminant calves. Res. Vet. Sci. 60:111-116.

Lehninger, A. L. 2001. Biosynthesis of amino acids, nucleotides and related molecules. Pages 887-937 in Lehninger Principles of Bio- chemistry. Vol. 3. D. Nelson and M. Cox, ed. Springer-Verlag, Berlin, Germany.

LeLeiko, N. S., A. D. Bronstein, B. S. Baliga, and H. N. Munro. 1983. De novo purine nucleotide synthesis in the rat small and large intestine: Effect of dietary protein and purines. J. Pedriatr. Gastroenterol. Nutr. 2:313-319.

Lowry, O. H., N. J. Rosebrough, A. L. Farr, and R. J. Randall. 1951. Protein measurement with the Folin phenol reagent. J. Biol. Chem. 193:265-275.

Markham, R. 1955. Nucleic acids, their components and related compounds. Pages 216-304 in Modern Methods of Plant Analysis. Vol. 4. K. Paech and M. V. Tracey, ed. Springer-Verlag, Berlin, Germany.

McCauley, R., S. E. Kong, and J. Hall. 1998. Glutamine and nucleotide metabolism within enterocytes. J. Parenteral. Enteral. Nutr. 22:105-111.

Montagne, L., I. Crévieu-Gabriel, R. Toullec, and J. P. Lallés. 2003. Influence of the dietary protein level and source on the course of protein digestion along the small intestine of the veal calf. J. Dairy Sci. 86:934-943.

Montagne, L., R. Toullec, T. Savidge, and J. P. Lallés. 1999. Morphology and enzyme activities of the small intestine are modulated by the dietary protein source in the pre-ruminant calf. Reprod. Nutr. Dev. 39:455-466.

Naumann, C., and R. Bassler. 1993. Die chemische Untersuchung von Futtermitteln. VDLUFA-Verlag, Darmstadt, Germany.

Núnez, M., J. Bueno, M. Ayudarte, A. Almendros, A. Rios, M. Suarez, and A. Gill. 1996. Dietary restriction induces biochemical and morphometric changes in the small intestine of nursing piglets. J. Nutr. 126:933-944.

Parks, D. A., and D. N. Granger. 1986. Xanthine oxidase: Biochemistry, distribution and physiology. Acta Physiol. Scand. Suppl. 548:87-99.

Perez, J. F., and P. Reeds. 1998. A new stable isotope method enables the simultaneous measurement of nucleic acid and protein synthesis in vivo in mice. J. Nutr. 128:1562-1569.

Razzaque, M. A., J. H. Topps, R. N. B. Key, and J. M. Brockway. 1981. Metabolism of nucleic acids of rumen bacteria by pre-ruminant and ruminant lambs. Br. J. Nutr. 45:517-527.

SAS Institute. 2004. SAS User's Guide: Statistics. Version 9.1 Ed. SAS Institute, Inc., Cary, NC.

Schlimme, E., D. Martin, and H. Meisel. 2000. Nucleosides and nucleotides: Natural bioactive substances in milk and colostrum. Br. J. Nutr. 84:59-68.

Schönhusen, U., and J. Voigt. 2004. Ruminal degradability of ${ }^{15} \mathrm{~N}$ labeled ribonucleic acid in grass. Arch. Anim. Nutr. 58:343-352.

Schönhusen, U., J. Voigt, and B. Piatkowski. 1988. Investigation on the use of RNA as marker for quantification of microbial protein synthesis in the rumen. Arch. Anim. Nutr. 38:289-297.

Seegraber, F. J., and J. L. Morrill. 1986. Effect of protein source in calf milk replacers on morphology and absorptive ability of small intestine. J. Dairy Sci. 69:460-469. 
Silva, A. G., J. T. Huber, T. H. Herdt, R. Holland, R. M. Degregorio, and T. P. Mullaney. 1986. Morphological alterations of small intestinal epithelium of calves caused by feeding soybean protein. J. Dairy Sci. 69:1387-1393.

Uauy, R., G. Stringel, R. Thomas, and R. Quan. 1990. Effect of dietary nucleosides on growth and maturation of the developing gut in the rat. J. Pediatr. Gastroenterol. Nutr. 10:497-503.

Voigt, J., and H. Steger. 1967. Quantification of ammonia, urea and ketone bodies in biological materials with a modified micro diffusion apparatus. Arch. Anim. Nutr. 17:289-293.
Witte, D. P., D. A. Wiginton, J. J. Hutton, and B. J. Aronov. 1991. Coordinate developmental regulation of purine catabolic enzyme expression in gastrointestinal and post implantation reproductive tract. J. Cell Biol. 115:179-190.

Wolfe, R. R., and D. L. Chinkes. 2005. Isotope Tracers in Metabolic Research: Principles and Practice of Kinetic Analysis. 2nd ed. Wiley-Liss, New York, NY.

Wutzke, K. D., W. Heine, T. Völker, F. Kreienbring, and K. Krawielitzki. 1984. Präparative Darstellung von hochangereichertem 15Nmarkiertem Hefeprotein. Isotopenpraxis 20:90-93. 